\title{
Phytoplankton association patterns in the deep southern subalpine lakes
}

(Part 1)

G. Morabito, N. Salmaso \& D. Ruggiu

(Guest Editors) 


\section{Preface}

Since the first meetings, usually held in Pallanza, of the Working Group on Deep Lakes (GlaP, Gruppo Laghi Profondi) the idea to compare the phytoplankton assemblages in deep southern subalpine lakes gradually grew up. We recognise that this isn't a new idea: since the papers by Pietro Pavesi (1877, 1879 a, b, 1883) and Rina Monti (1929) until the most recent years (i.e. Ruggiu 1983; Ambrosetti et al. 1992) similar comparisons have been already done. However, we feel that the analysis presented in this and the next issue of Journal of Limnology will offer many new subjects: the study is not only a comparison of taxonomic lists, but is focused on phytoplankton assemblages and their seasonal dynamics; the data from the different lakes have been collected during the same time period, with similar periodicity and fully comparable sampling techniques and strategies; the methods used to analyse the samples and to treat the data are the same. Due to the full comparability of the data collected, it has been possible to study the seasonal dynamics of the phytoplankton assemblages in the whole subalpine lake district, across a trophic, geographic and climatic spectrum. Moreover, the analysis described here was a useful tool for recognising a common succession pattern in the southern deep subalpine lakes.

We are confident that this collection of papers on the phytoplankton in the deep southern subalpine lakes can represent a starting point towards the possibility to answer questions as: what kind of changes should we expect in the phytoplankton assemblages following future increases or decreases of the nutrient loads? Which are the environmental conditions favouring the growth and, eventually, the bloom of certain algae (i.e. cyanobacteria)? What species assemblage could be the most typical in the subalpine lake district?

We intended to publish in a single monographic volume all the articles dealing with this topic, but editorial and technical reasons made it impossible to realise this wish: the papers will therefore be splitted into two consecutive issues of Journal of Limnology.

Giuseppe Morabito, Nico Salmaso, Delio Ruggiu

\section{REFERENCES}

Ambrosetti, W., L. Barbanti, R. Mosello \& A. Pugnetti. 1992. Limnological studies on the deep southern Alpine lakes Maggiore, Lugano, Como, Iseo and Garda. Mem. Ist. ital. Idrobiol., 50: 117-146.

Monti, R. 1929. Limnologia comparata dei laghi insubrici. Verh. int. Ver. Limnol., 4: 462-497.

Pavesi, P. 1877. Intorno all'esistenza della fauna pelagica o d'alto lago anche in Italia. Bull. Entomol., 9: 293-298.

Pavesi, P. 1879a. Nuova serie di ricerche sulla fauna pelagica dei laghi italiani. Rendic. R. Ist. Lomb., 12 (16): 688707.

Pavesi, P. 1879b. Ulteriori studi sulla fauna pelagica dei laghi italiani. Rendic. R. Ist. Lomb., 12 (11-22): 474-483.

Pavesi, P. 1883. Altra serie di ricerche e studi sulla fauna pelagica dei laghi italiani. Atti Soc. Ven. Trent. Sc. Nat., 8: 340-403.

Ruggiu, D. 1983. Caratteristiche e comportamento del fitoplancton nei laghi profondi sudalpini. In: W. Ambrosetti, L. Barbanti, R. Mosello, A. Rolla \& D. Ruggiu, Mescolamento, caratteristiche chimiche, fitoplancton $e$ situazione trofica nei laghi profondi sudalpini. C.N.R. AQ/2/20: 105-145. 


\title{
Phytoplankton in deep Italian lakes: introductory remarks
}

\author{
Delio RUGGIU \\ CNR Istituto per lo Studio degli Ecosistemi, L.go V. Tonolli 50, 28922 Verbania Pallanza, Italy
}

I will try here to enlarge and shortly qualify the presentation to this series of papers on the deep Italian subalpine lakes that can be read on the preceding page. The following considerations originate from several group meetings we had usually in Pallanza, but in part are my own and do not necessarily reflect all the specific beliefs of the participating members. But I feel that some basic beliefs are truly shared, particularly those that stimulated our activity on the phytoplankton of these lakes in the first place.

Those who first implemented a concerted effort on the deep subalpine lakes (Mosello \& Giussani 1997), had a prevalent interest in the quality of the lake waters, a topic of great importance in that vast region which, except in the mountainous part of the basins, is overpopulated, overexploited, swarmed by tourists. Though biology was not totally kept aside, the main focus was on the lakes' chemical and physical properties relevant to the trophic states, and consequently, on what was done and remained to be done on that matter from a practical side. The authors intended to adopt a largely comparative approach, and the reason for this came not only from the lot of papers existing on the subject on single lakes, but also from the deep-seated belief, starting from some classic, early papers by Vollenweider $(1964,1965)$, that comparisons were fruitful in a region which, though large, could be considered as a unit in many respects.

Shortly after the initiation of the project, a sub-group on the phytoplankton of the deep Italian subalpine lakes (DSL) spontaneously formed, composed by the people who have signed the respective papers in the present and the following issue of this Journal, and whose principal interest lies in the phytoplankton. We realised that a lot of research was made on the DSL phytoplankton in the last century, and more intensely in the last few decades, by many people and Institutions. However, the papers of a comprehensive nature are very few -nearly all are mentioned in the Presentation- so that we felt that an effort was overdue to characterize, and compare, the algal associations of the DSL in their development, composition, seasonality, etc., and maybe, with luck, to establish some typical traits of a phytoplankton insubrian community.

The material at hand was abundant. Of the five lakes on wich we report, those in the west (Maggiore and Lugano) have been the object of a continuous monitor- ing on behalf of an Italo-Swiss Commission for over 20 years; at the far, east side, Lake Garda is being systematically monitored for several years; among the remaining lakes, Como has been studied discontinuously over the years, while Iseo, though not regularly monitored, was the object of many comprehensive studies in the last two decades or so. A lot of data on the phytoplankton are reported in much older papers which, scanty and unconnected as they are, furnish often invaluable material for comparison with the regular series of today.

From this context we left out Lake Orta, a deep subalpine lake in its own right, because about 12 years ago it was subjected to a liming treatment after a longterm, severe industrial pollution. Algal communities are now redeveloping at a quick rate, but they are not yet comparable to those of the other DSL, and L.Orta is still unique (its case history, including the phytoplankton, is reported in several papers, e.g. Calderoni et al. 1992). What is interesting with this lake from the point of view of this discussion is that the liming to which the lake was subjected, with thousands of calcium carbonate tons dumped in it, was an experiment on a big scale performed on a large lake, something that is nearly impossible in most cases. As very large and immediate modifications followed the liming, we could reasonably ascribe the effects to their obvious cause. Precisely the phytoplankton was most intensely modified, and as a striking example, the diatoms, that for years were very rare in the plankton samples, had a tremendous, immediate development that made them the dominant organisms in the lake. Facts like these can provide, so to say at a stroke, significant insights into the ecology of the algae.

However, in most cases the practice of limnology is observational, as is often the case with studies in nature, and as it surely was with the DSL activities reported in our set of papers. There are many who presume that observations, or descriptions, are second-rate science, but I feel that this is not necessarily so, just as bad experiments are not good science. We may agree with an old claim by Talling (1984), that not rarely so-called experiments are in fact observations; besides, the latter are often difficult to make but can give valuable knowledge of the setup and relations in an ecosystem.

But in order to get such insights, long-term studies are a prerequisite. Further, we must be honest and not 
expect to demonstrate the "functioning" of the system with a sampling programme, however well planned. Real experiments are usually needed in this respect. On the other hand, even though laboratory experiments can add much to our knowledge of physiological potentialities of particular algal species or of the outcome of competition among a few species, rarely can they permit predictions of the algal behaviour in the field. A step farther are in situ experiments such as those with large tubes mimicking the conditions in the lake up to a certain point. It may seem trivial, but the only way to know what is happening in the field is to go over there and start an accurate sampling programme coupled with a monitoring of the physical, chemical and meteorological variables known or thought to be relevant to the wax and wane and uninterrupted variations of the phytoplankton.

This is not a simple task, however. An overview of what we expect from the present series of papers will show it. First of all we want to recognize patterns, i.e. typical, repeated configurations of objects and events, and, when occurring, sudden events or slow or sudden transition stages. The key point is that such facts must be unquestionably proven if they are to be of any value, because, while carrying important information in themselves, they are the basic stuff from which speculations, hypotheses and whatsoever concerning the functioning of the system is made. We feel that presently we need much more proved facts of this kind, possibly on a longterm scale, than more speculations on the functioning of lakes, of which a lot of papers are stuffed, sometimes on an insufficient factual basis. This was at any rate the inspiration of the paper by Ruggiu et al. (1998) on the oligotrophication of Lake Maggiore; to give just an example of what can be achieved by this approach, we could prove, with time series and simple statistics, that there was an unmistakable, remarkable, abrupt but then permanent reduction of average algal cell size with time. Considering that theoretical arguments are still found in the literature on whether algal cell size must be larger or smaller with changing trophic state, this result was exciting enough for us.

We shall therefore ascertain if more generalisations on characteristics or behaviour of algal assemblages can be made (meaning rigorously proven) over the entire set of DSL, or at least in part of them, through an analysis to be presented in a final, synoptical paper in the next issue of this Journal.

The second purpose is connected with the first and with a more difficult question, i.e. the ability to predict which species will form an assemblage, and possibly their growth state (e.g. blooms), at a specific time in given environments or part of them. This is possibly the basic question in ecology, but most ecologists will admit that, notwithstanding the uncounted papers on this subject, it is a question still largely unanswered. It would be too long to analyse the reasons for this state of affairs, which anyway depend on a large number of elusive factors acting both in space and time. Partial answers and theoretical treatment are found in the seminal paper by Margalef (1978), while a big effort is being made by Reynolds (1997) in his already monumental, life-long work, to mention only two in a deserving list of authors.

Indeed, this part of our investigation was chiefly inspired by Reynolds' achievements. Working mostly in the English Lake District, he was able to identify over the years a high number of phytoplankton assemblages demonstrably typical of many diversified environmental situations, like nutrient availability and trophic state of lakes, their morphology and hydrology, thermal and mixing regime, time of the year and so on. There are investigators who are currently comparing the algal assemblages they are studying with those of Reynolds, an operation which will also be found in some of the following papers. However, it would be odd to assimilate assemblages from various part of the world to some described by Reynolds in the UK. It is likelier, or so we believe, that different lake districts will exhibit their own associations, and this we will try to ascertain in the final paper, at least tentatively, for the deep subalpine lake district in Italy.

\section{REFERENCES}

Calderoni, A, R. Mosello \& D. Ruggiu. 1992. Sixty years of limnology in Lago d'Orta: a case history of recovery from heavy pollution. Mem. Ist. ital. Idrobiol., 50: 201-223.

Margalef, R. 1978. Life-forms of phytoplankton as survival alternatives in an unstable environment. Oceanologica Acta, 1: 493-509.

Mosello, R. \& G. Giussani (Eds). 1997. Evoluzione recente della qualità delle acque dei laghi profondi sudalpini (Recent evolution of water quality of deep southern alpine lakes). Documenta Ist. ital.Idrobiol., 61, 228 pp.

Reynolds, C.S. 1997. Vegetation processes in the pelagic: a model for ecosystem theory. In: O.Kinne (Ed.), Excellence in Ecology. Ecology Institute, Oldendorf/Luhe: $371 \mathrm{pp}$.

Ruggiu, D., G. Morabito, P. Panzani \& A. Pugnetti. 1998. Trends and relations among basic phytoplankton characteristics in the course of the long-term oligotrophication of Lake Maggiore (Italy). Hydrobiologia, 369-370: 243-257.

Talling, J.F. 1984. Past and contemporary trends and attitudes in work of primary productivity. J. Plankton Res., 6: 203217.

Vollenweider, R.A. 1964.Ueber oligomiktische Verhältnisse des Lago Maggiore und einiger anderer insubrischer Seen. Mem.Ist. ital. Idrobiol., 17: 191-206.

Vollenweider, R.A. 1965. Materiali ed idee per una idrochimica delle acque insubriche. Mem.Ist. ital. Idrobiol., 19: 213-286. 